\title{
EDUCATION FOR SECURITY VERSUS EDUCATION FOR SUSTAINABLE DEVELOPMENT
}

\begin{abstract}
The article presents issues related to the practice of sustainable development against the background of selected strategies and models of education. In the face of the ecological crisis, as well as growing threats to the social and natural environment, the need to modify education for sustainable development programmes appears more apparent. It has been proposed that this model of education should be supported by education for security, since security is a need, value, and a dynamic social process, and any actions in its favour, offer a strong incentive for people to be active and adopt new attitudes.
\end{abstract}

Keywords: sustainable development, education for security, education for sustainable development, school education, sustainable development practice

\section{Introduction}

Contemporary environmental threats make us aware of the need to modify the theory of education for sustainable development and security. Developing education curricula in this area has, for several decades, been considered a priority for the pedagogical, natural, economic, and philosophical sciences. Attention is drawn to the necessity of educating people, who will not remain indifferent towards global problems, and who will be aware of civilisation threats to the social and natural environment.

The theoretical assumptions behind the idea of sustainable development have been developed well enough, to make it easy to indicate the desired directions of changes and aspirations that guarantee human security. However, the adopted

\footnotetext{
* Dr Agnieszka Klimska, Cardinal Stefan Wyszyński University in Warsaw, Institute of Pedagogy, e-mail: a.klimska@uksw.edu.pl.
} 
prospective strategies, including those related to education, are unfortunately, rarely reflected in social practice. Therefore, it seems plausible to understand sustainable development as a method of finding such a solution and standards of human action that will lead to harmonious co-existence (Grochowska 2009).

The present article will address the issues related to the practice of sustainable development in relation to exemplary strategies and models of education. The main goal is to emphasise why the category of security and elements of education for security should be included in education for sustainable development programmes.

\section{Proposals and stipulations of education for sustainable development}

Education seems to be one of the most effective tools on the way to achieving the goals of sustainable development. Therefore, shaping the education system towards sustainable development is essential in creating conditions suitable for the challenges of development understood in terms of sustainability. The assumptions of education for sustainability can be found in most international and national post-conference documents and publications and proceedings. The need to re-organise the educational system, in response to the challenges faced by mankind, was noticed back in 1969, after the publication of the Sithu U Thant Report titled Man and His Environment (Domeradzki, Tyburski 2011). International debates about the future of education were a direct consequence of the global ecological crisis signalled in the report, brought about by a technocratic and irrational attitude to the natural environment, which was disturbing its balance. Education was first recognised as a pre-requisite for the implementation of sustainability by three groundbreaking global summits for sustainable development: the 1992 UN Conference on Environment and Development in Rio de Janeiro, Brazil; 2002 World Summit on Sustainable Development in Johannesburg, South Africa; the UN conference in 2012, again in Rio de Janeiro (Batorczak, Klimska 2020). An important milestone was marked by the agreement achieved during the 1992 Earth Summit, when the Global Programme of Action was adopted. The Programme stressed the necessity of making knowledge and information about the environment accessible to all people. It also underlined the need to verify the existing education projects, and to include issues related to the concept of sustainable development in the education process. This question was further elaborated and clarified within the UNESCO initiative, i.e., the UNESCO World Conference on Education for Sustainable Development (Hłobił 2010). The present form and scope of this education was significantly influenced by the assumptions and goals adopted by the UN General Assembly: Decade of Education for Sustainable Development 2005-2014. This document has been recognised as one of the key international initiatives advocating a comprehensive change in the education system. It focuses primarily on the need to promote sustainable activities in the economy, society, and the natural environment. The authors of the Decade emphasised the importance of balancing socio-economic goods, natural 
resources, and culture, whilst respecting human dignity, bio-diversity and taking into account the principles of environmental protection. Moreover, the document highlighted the urgency to raise the quality of education by guaranteeing that each person can develop his or her own preferences and choices. In accordance with the Decade's proposals, the process of education should include activities aimed at instilling values conducive to the implementation of sustainable development guidelines, and it should be constantly monitored and improved. It is an initiative, directed at human capital, that may lead to developing new skills and to providing new experiences, that manifest the progressing implementation of sustainable development principles (Jabłoński 2010).

On the basis of the assumptions of the Decade of Education for Sustainable Development, the United Nations Economic Commission for Europe in 2005, developed and adopted the Strategy for Education for Sustainable Development. The document's goals correspond to those formulated in the Decade and continue its assumptions. The Strategy proposes including the basic issues of sustainable development in formal and non-formal education systems, with particular emphasis on such issues as dignity and human rights, the fight against poverty, health, quality of life, security, social justice, protection and management of the natural environment, as well as issues from the area of ethics, the economy, and culture (Borys 2010a).

The essential actions based on the principles and values of sustainable development defined in the Decade, primarily included:

- promoting and raising the quality of education, by indicating the values, and developing the skills necessary to improve people's lives;

- modifying the scope of training and educational projects, in view of the fact that all levels of education need to be reconsidered and, consequently, it is necessary to develop programmes that convey knowledge about, for example, the values which play a key role in implementing the postulates of sustainable development;

- developing social awareness and promoting acceptance of the concept adopted in the Decade;

- promoting lifelong learning, expanding the group of participants in the process of education for sustainable development (Web-1).

Sustainable development is currently implemented, according to the guidelines defined as 17 Sustainable Development Goals (Web-2), which the international community should strive to achieve by 2030. Each of the goals adopted at the 7oth UN Session in September 2015, addresses the issue of effective education. Objective 4 - "Ensure inclusive and equitable quality education and promote lifelong learning opportunities for all" - especially strongly emphasises the role of education in achieving sustainable development (Klimski 2018).

It is important that the educational process proposed in the strategies, and based on agendas, should aim at implementing tasks ensuring a sustainable future and 
the desired socio-economic transformations. This theoretical model of education should lead to introducing fundamental changes in the education system, and to re-formulating that system in such a way that the curricula, content, and forms of education may incorporate a new vision of development, combining, at least, the three interrelated key areas: the natural environment, society, and the economy. Therefore, "[...] it is necessary to depart from the narrow understanding of education, which emphasises only the 'rational' side (intellect, intellectual rationalism), and refers only to a small extent, to new development paradigms [...]" (Borys 2010b, p. 59). On the other hand, it is important to create and promote educational programmes going beyond theory, and thus, potentially, capable of developing skills, or possibly also social competences, which, by influencing the sphere of the recipients' awareness, may contribute to building an order based on sustainable development.

\section{The category of security in the concepts of sustainable development}

The concept of security belongs to a category that is quite often associated with issues and research related to the international order, civilisation threats, or sustainable development, especially in the situation of the changing social, economic, and cultural spaces. Security and the sense of security are currently considered as essential values. The very term "security" derives from the Latin word securitas, and it has taken on multiple meanings today. Security is identified primarily with a sense of certainty, safety, and lack of threats. However, more and more often, the idea of security is presented in its broader meaning, going beyond its general social understanding, and taking into account the specificity of international relations, namely, the so-called holistic approach. Thus, security means more than a sense of freedom from threats and fears, since it is additionally defined as a lack of political and economic pressure, with the possibility of pursuing one's own development, maintaining, or improving the quality of life, or having the ability to survive in the face of existential threats. Security is, therefore, not only a need or a value, but also a dynamic social process. Thus, there has been a noticeable shift from a static to a dynamic perception of security (Pietraś 20oo). Such a change has been undoubtedly influenced by events, scientific studies, or reports that focused on global threats, and the ecological crisis (e.g., the report The Limits of Growth or the aforementioned U Thant Report), and thus, forced a narrow outlook on the future, taking specific preventive and organisational actions. It is the scale and nature of the changes that took place in Europe, in the second half of the 2oth century, that influenced the scope and formula of "security". The paradigm of security has changed as a result of the increasing interdependence of states, the rising role of international institutions and non-governmental organisations, as well as with the evolution of threats. Transformations taking place worldwide require international co-operation, also, in regard to providing security. What is important today, 
however, is security understood in a more dynamic way, taking into account the long-term perspective (Pietraś 2000).

Consequently, the development of the category of security also involved reflection on global, environmental threats. In this sense, the concept of security or ecological security is closely related to the general idea, as well as particular concepts of sustainable development. The discourse on the issue of ecological security has gained special importance at a time of increasing ecological threats. At that time, people began to realise the consequences of the wrong relationship between man and the natural environment. The end of the 1960 s can, therefore, be considered a breakthrough in the perception of environmental problems, which resulted mostly in activities aimed at eliminating changes in the environment that were unfavourable to humans. The aim, therefore, was to undertake projects allowing the minimisation of the existing or potential threats to human health and life, arising from the environment (Zięba 1998). Developed in this context, the question of ecological security, along with the growing importance of the idea of sustainable development, was expanded by economic, social, and political aspects. Therefore, the concept of ecological security goes beyond protection of social systems based on care for the natural environment, and it comprises activities supporting the strengthening of the external security of the state. M. Pietraś, aiming to emphasise the substantive scope of the category of ecological security, went beyond its solely "eco-systemic" understanding and stressed the importance of the impact of ecological processes generating threats to human health and life, and affecting the existing local, regional, and global instabilities. Pietraś contended that ecological security should be defined as "[...] such a state of social relations, including the content, forms and ways of organising international relations, which not only reduces or eliminates environmental threats, but also promotes positive actions, enabling implementation of values, essential for the existence and development nations and states" (Pietraś 2000, p. 85). It is worth remembering that one of the biggest threats to the social and natural environment is "[...] human lack of sensitivity to the far-reaching negative effects of current activities [...] and civilisation traps, resulting from a naive fascination with projects aimed at promoting the welfare of humanity" (Łepko, Sadowski 2020, p.7).

Strengthening the importance of the anthropogenic profile of environmental threats and promoting the role of international co-operation in developing legislation on environmental protection and changing social behaviours, can be considered as initiatives congruent with, and supporting the majority of sustainable development strategies, including those comprising projects related to education and upbringing. 


\section{Education for sustainable development and education for security in Poland}

The concepts of ecological education, environmental education, and education for sustainable development, are often presented as synonymous in literature. Currently, however, it is difficult to disagree that environmental education is part of education for sustainable development, and it is considered as one of the key tools in implementing this development. The document presented by the Ministry of the Environment in 2001, "Through Education to Sustainable Development. National Strategy for Environmental Education" presented the possibilities of organising and implementing ecological education in Poland, as a task falling into the scope of a broader strategy aimed at building a sustainable future. This education was recognised as an essential component of civic education "[...] aimed at developing a rational society, and accepting the principles of sustainable development, capable of assessing the state of environmental security and participating in decision-making processes" (Web-3).

One of the most important Polish documents showing a model education programme, comprising issues of sustainable development is "Poland 2025 Long-term strategy for sustainable development". The document defined the tasks illustrating a new approach to the education system. It expressed the urgency to develop such a model of education, which would include changing the methods and goals of teaching. It is postulated that the adopted new forms of education should go beyond the traditional approach, based primarily on the transfer of knowledge. The learning processes should be focused on achieving such outcomes as knowledge, skills, and competences. Education should concentrate especially on achieving the learning outcomes in the scope of key, social competences in specific areas. The Strategy implies, moreover, that nowadays, it is important to increase the culture-forming function of education. This can be accomplished by engaging in the education process various cultural environments and institutions, mass media, families, etc., and by promoting the importance and intensive development of non-formal and informal education. The document also emphasises the need to intensify activities, aimed at developing environmental education as a measure supporting protection of the natural environment and implementation of sustainable development guidelines (Web-4).

A similar position on educational issues is adopted in the document: "Sustainable Development Strategy for Poland up to 2025", which postulates that successful implementation of the concept of sustainable development is conditioned by "[...] active participation of well-informed and well-educated society" (Web-3). Properly directed education enables the shaping and educating of people into individuals capable of making conscious decisions and intentional choices, and actively participating in the implementation of common goals and aspirations, focused on sustainable development. Therefore, education should be conducted on an ongoing basis, through various programmes, with the use of diverse forms and 
methods. Moreover, all levels of education, despite their differences, should have a common denominator in the form of recognising in each activity interactions and couplings between ecological, social, and economic aspects.

The necessity to depart from the teaching system based on the transfer of knowledge, followed by its assimilation through memorizing specific content and patterns, was expressed in the document: "Poland 2030. The third wave of modernity. Long-term National Development Strategy" (Web-6). The document highlights the necessity of implementing an education reform, including, among others:

- development of competences;

- personalisation of teaching;

- assessment of problem-solving skills;

- rationing the prevalence of traditional forms and methods of teaching in favour of group work and joint implementation of team projects;

- strengthening the importance of education for sustainable development;

- promotion of modern communication and information technologies as teaching aids;

- systematic evaluation and possible revision of curricula.

These guidelines are also often emphasised in relation to the broadly understood education for security, which, similarly to education for sustainability, is currently associated with most spheres of human existence.

Today, security means much more than a lack of threats. "Security is more and more often viewed from the perspective of certain defining features, values and goals" (Klimek 2004, p. 25). Those include, among others, the certainty of existence, the possibility to develop and to be active, or to satisfy basic needs, as well as having a sense of stability or living in prosperity. The processes of shaping a secure future, include not only programmes and strategies related to education for sustainable development, but in particular, all activities carried out within the socalled education for security. There are various definitions of this type of education. On the one hand, education for security is understood simply as dissemination of knowledge about contemporary threats, and on the other as, educating people to work, to fight, to be active, and to strengthen security. This education also touches upon the wisdom of thinking about security which, following K. Klimek, is understood as perceiving the future, and which is associated with entities dealing with the creation of knowledge, laws, principles, and social rules (Klimek 2004).

Education for security in Poland has been included in the list of subjects taught in primary schools since 2009, and in secondary schools since 2012. In the core curriculum of general education, it has been explained that this type of education is aimed at preparing students to behave properly, and to react appropriately in situations of threat to health and life. State security, on the other hand, is understood as "[...] an area of knowledge that explains the mechanisms of ensuring law, order, and the stability of human communities, as well as the accompanying concepts, 
methods, and forms of conduct" (Web-7). Education in the scope of security has an interdisciplinary character and is focused on developing students' ability to recognise threats, and to act effectively in emergency situations. In the core curriculum, a lot of space is devoted to the issues of rescue, first aid, and health education. Civilisation threats to the social and natural environment have been treated marginally. Therefore, it is imperative to prepare people to take actions, ensuring their survival and development, also in situations of threats to security, arising from the environment. It is moreover necessary to educate people how to respond to these threats by shaping their adaptive skills, but also to implement projects limiting both the causes and effects of the threats.

\section{Supporting education for sustainability with education for security strategies}

Realisation of the idea of sustainable development is a process involving whole societies, as well as each individual. However, implementation of particular recommendations falling into the scope of the policy and actions at the national and local levels, can be difficult due to their entanglement in specific technical, economic, political, and social conditionings (Zacher 2009). Most sustainable development strategies, despite their specific theoretical assumptions, are not reflected in practical activities. Education that takes into account the integrated grounds (especially economic, social and ecological) of sustainable development, still remains in the sphere of wishful thinking. This process lacks a systemic approach or radical actions on the part of institutions responsible for education.

Education for environment can only be effective when it gets through to society via all possible means, and in all forms. It is necessary to create models of education adapted to specific conditions and equipped with appropriate didactic resources, to select appropriate methods and techniques of transferring information, and of practical applications of knowledge. Education for environment consists, not only in transferring sound and reliable knowledge, but most importantly, in involving people in activities for the social and natural environment, in holistic development of each individual, in building a sense of responsibility for the lives of the present and future generations, and in striving to inculcate such an axiological system that would consider all manifestations of human activity in the natural environment, society, and economic processes. Such an education is not sufficiently supported within school and lifelong education. That is why it is necessary to support it, amongst others, by education for security.

The need for security is one of the most important human aspirations. Activities aimed at satisfying both individual and social security were major goals of the earliest societies. Over time, the methods and means used to satisfy this need have changed, but security has, overall, remained a priority value.

Education for security is a process rooted in primary psychological conditions, as well as in the axiological sphere (Elak 2017), therefore, it should become part of 
education for sustainability. The functions that education for security performs, especially the cognitive function (recognising current and potential threats), the regulatory function (shaping relations with the environment) and the modifying function (changing the attributes of an entity adequately to the existing threats), (Elak 2017), are crucial in providing an effective response to global problems, including threats to the social and natural environment. Education for security can, therefore, provide significant support for education for sustainability. Strategies of actions for security, which are created and undertaken with a view to counteracting specific threats to human health and life, have a much more powerful effect on people, prompting them to act.

\section{Conclusion}

In Polish schools, education for sustainable development and education for security in the scope of environmental threats, are provided in a fragmentary manner and lack a curriculum. The former is referred to in the teaching content of, for example, biology, chemistry, or ethics, but the decision whether, and to what extent, to discuss selected issues rests with the teacher. In practice, the issues discussed more widely in schools are those related to environmental education. Education for security, on the other hand, has been reduced to rescue, first aid, and health education.

Both education for sustainable development and education for security should place the emphasis on shaping social and political awareness and strive to prepare people for the future. Both types of education which involve propagation of specific values, provide a response to global problems and civilisation threats, which are sometimes simply variously identified or defined. What is important is the perception of the future, as well as anticipation of threats, but priority should be given to actions and deliberate undertakings motivated by concern and a sense of responsibility for the present and future reality, as well as for the security of our own and future generations.

The approach to education proposed in the cited documents, including education for sustainability, may constitute the theoretical basis for models or specific programmes for the implementation of sustainable development postulates. However, rather less frequent are projects or educational activities that combine the category of security and are promoted by education for security, with initiatives implemented as part of education for sustainable development. Consequently, there is a paucity of plans or programmes which, by adopting theoretical assumptions developed in the above-mentioned documents and guidelines, e.g., educational ones, would propose a specific model of operation, whose implementation could be considered as a "tangible" proof of practical implementation of the tasks arising from aspirations towards sustainable development, and thus, a secure future. 


\section{Bibliography}

Batorczak A., Klimska A. (2020). Edukacja na rzecz zrównoważonego rozwoju refleksje przed ogłoszeniem nowej Dekady na rzecz Zrównoważonego Rozwoju (2020-2030). „Studia Ecologiae et Bioethicae”, vol. 18 (2), s. 17-26.

Borys T. (2010a). Dekada edukacji dla zrównoważonego rozwoju - polskie wyzwania. „Problemy Ekorozwoju”, vol. 5, nr 1, s. 59-70.

Borys T. (2010b). Zrównoważony rozwój jako wyzwanie edukacyjne. W: Edukacja dla zrównoważonego rozwoju. Borys T. (red.). Białystok-Wrocław: Wydawnictwo Ekonomia i Środowisko.

Domeracki P., Tyburski W. (2011). Podstawy edukacji i kształtowania świadomości społecznej w duchu zrównoważonego rozwoju. W: Zasady kształtowania postaw sprzyjających wdrażaniu zrównoważonego rozwoju. Tyburski W. (red.). Toruń: Wydawnictwo UMK.

Elak H. (2017). Edukacja na rzecz bezpieczeństwa w świetle nowej reformy oświaty. „Obronność. Zeszyty Naukowe”, vol. 3 (23), s. 17-41.

Grochowska I. (2009). Wychowanie do zrównoważonego rozwoju w kontekście katolickiej nauki społecznej. „Studia Ecologiae et Bioethicae”, vol. 7/2, s. 123-137.

Hłobił A. (2010). Teoria i praktyka edukacji ekologicznej na rzecz zrównoważonego rozwoju. „Problemy Ekorozwoju”, vol. 5, nr 2/2010, s. 87-94.

Jabłoński M. (2010). Legal conditions for sustainable development. W: A humanist approach to sustainable development. Łepko Z., Sadowski R. (red.). Warszawa: Wydawnictwo UKSW.

Klimek K. (2004). Bezpieczeństwo w systemie wartości uniwersalnych w edukacji. W: Edukacja dla bezpieczeństwa. Wybrane perspektywy. Kowalski D., Kwiatkowski M., Zduniak A. (red.). Lublin-Poznań.

Klimski M. (2018). Call for high quality education in the context of the postmodern society conception. „Zeszyty Naukowe Politechniki Śląskiej. Seria: Organizacja i Zarządzanie", vol. 122, s. 81-89.

Łepko Z., Sadowski R.F. (2020). Paradoksalne konsekwencje nowożytnego projektu panowania człowieka nad przyroda. W: Paradoksy ekologiczne. Odpady miara sukcesu i porażki cywilizowanej ludzkości. Warszawa: KSAP.

Pietraś M. (200o). Bezpieczeństwo ekologiczne w Europie. Studium politologiczne, Lublin: Wydawnictwo UMCS.

Zacher L.W. (2009). Modele, strategie, uwarunkowania i konteksty trwałego rozwoju. W: Poskrobko B. (red.). Zrównoważony rozwój gospodarki opartej na wiedzy. Białystok: Wydawnictwo Wyższej Szkoły Ekonomicznej.

Zięba S. (1998). Dylematy bezpieczeństwa ekologicznego. Lublin: Zakład Ekologii Człowieka Katolickiego Uniwersytetu Lubelskiego. 


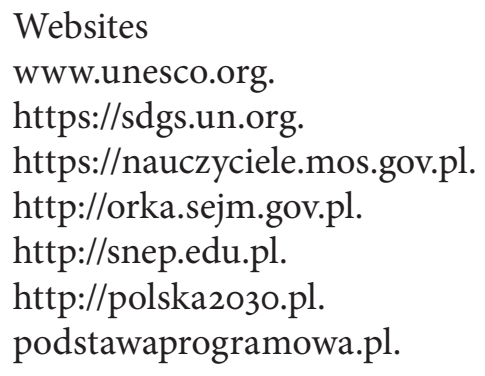

\section{EDUKACJA DLA BEZPIECZEŃSTWA VERSUS EDUKACJA NA RZECZ ZRÓWNOWAŻONEGO ROZWOJU}

Streszczenie: $\mathrm{W}$ artykule został przedstawiony problem praktyki zrównoważonego rozwoju w odniesieniu do wybranych strategii i modeli edukacji. W sytuacji nasilających się zagrożeń dla środowiska społeczno-przyrodniczego i kryzysu ekologicznego uwidacznia się potrzeba modyfikowania programów edukacji sustensywnej. Zaproponowano, aby edukację tę wspierać przedsięwzięciami realizowanymi w ramach edukacji dla bezpieczeństwa. Bezpieczeństwo jest bowiem potrzebą, wartością i dynamicznym procesem społecznym, a działania na jego rzecz silniej mobilizują ludzi do aktywności i zmiany postaw.

Słowa kluczowe: zrównoważony rozwój, edukacja na rzecz bezpieczeństwa, edukacja sustensywna, edukacja szkolna, praktyka zrównoważonego rozwoju. 